\title{
Effect of Nitrous Oxide on Excitatory and Inhibitory Synaptic Transmission in Hippocampal Cultures
}

\author{
Steven Mennerick, ${ }^{1}$ Vesna Jevtovic-Todorovic, ${ }^{2}$ Slobodan M. Todorovic, ${ }^{2}$ Weixing Shen, ${ }^{1}$ John W. Olney, ${ }^{1}$ and \\ Charles F. Zorumski ${ }^{1}$
}

Departments of ${ }^{1}$ Psychiatry and ${ }^{2}$ Anesthesiology, Washington University School of Medicine, St. Louis, Missouri 63110

Nitrous oxide $\left(\mathrm{N}_{2} \mathrm{O}\right.$; laughing gas) has been a widely used anesthetic/analgesic since the 19th century, although its cellular mechanism of action is not understood. Here we characterize the effects of $\mathrm{N}_{2} \mathrm{O}$ on excitatory and inhibitory synaptic transmission in microcultures of rat hippocampal neurons, a preparation in which anesthetic effects on monosynaptic communication can be examined in a setting free of polysynaptic network variables. Eighty percent $\mathrm{N}_{2} \mathrm{O}$ occludes peak NMDA receptor-mediated (NMDAR) excitatory autaptic currents (EACs) with no effect on the NMDAR EAC decay time course. $\mathrm{N}_{2} \mathrm{O}$ also mildly depresses AMPA receptor-mediated (AMPAR) EACs. We find that $\mathrm{N}_{2} \mathrm{O}$ inhibits both NMDA and non-NMDA receptor-mediated responses to exogenous agonist. The postsynaptic blockade of NMDA receptors exhibits slight apparent voltage dependence, whereas the blockade of AMPA receptors is not voltage dependent. Although the degree of ketamine and $\mathrm{Mg}^{2+}$ blockade of NMDA-induced responses is dependent on permeant ion concentration, the degree of $\mathrm{N}_{2} \mathrm{O}$ blockade is not. We also observe a slight and variable prolongation of $\mathrm{GABA}_{\mathrm{A}}$ receptor-mediated (GABAR) postsynaptic currents likely caused by previously reported effects of $\mathrm{N}_{2} \mathrm{O}$ on $\mathrm{GABA}_{\mathrm{A}}$ receptors. Despite the effects of $\mathrm{N}_{2} \mathrm{O}$ on both NMDA and non-NMDA ionotropic receptors, glial glutamate transporter currents and metabotropic glutamate receptor-mediated synaptic depression are not affected. Paired-pulse depression, the frequency of spontaneous miniature excitatory synaptic currents, and high-voltage-activated calcium currents are not affected by $\mathrm{N}_{2} \mathrm{O}$. Our results suggest that the effects of $\mathrm{N}_{2} \mathrm{O}$ on synaptic transmission are confined to postsynaptic targets.

Key words: NMDA receptor; glutamate; nitrous oxide; GABA; postsynaptic; presynaptic
Despite much attention, cellular mechanisms underlying general anesthesia remain elusive. Many anesthetics share the ability to potentiate exogenously or synaptically generated $\mathrm{GABA}_{\mathrm{A}}$ receptor-mediated (GABAR) currents (Franks and Lieb, 1994). Halothane, isofluorane, barbiturates, neurosteroids, and propofol are examples of known anesthetic $\mathrm{GABA}_{\mathrm{A}}$ modulators. Some anesthetics like halothane inhibit high-voltage-activated calcium currents (Herrington et al., 1991; Miao et al., 1995), suggesting the possibility that presynaptic effects contribute to some of the anesthetic actions of these agents. Inhibitors of NMDA glutamate receptors, like ketamine, phencyclidine, and MK-801, have anesthetic properties, with ketamine enjoying widespread clinical use in pediatric populations.

Nitrous oxide $\left(\mathrm{N}_{2} \mathrm{O}\right)$ has been used as an inhalation anesthetic for over a century and as a recreational drug of abuse since at least the 18th century; yet the mechanism(s) of the effects of nitrous oxide on signaling in the CNS is not understood. $\mathrm{N}_{2} \mathrm{O}$ is widely used clinically because of its good analgesic properties; however, it is a relatively weak anesthetic, requiring high volume percent and hyperbaric conditions to achieve the minimal alveo-

Received Aug. 10, 1998; revised Sept. 15, 1998; accepted Sept. 21, 1998.

This work was supported by a Lucille P. Markey Postdoctoral Fellowship (S.M.); by a Foundation for Anesthesiology Education and Research/Abbott New Investigator Award (V.J.-T.); by National Institutes of Health Grants AG11355 (J.W.O), DA05072 (J.W.O), MH45493 (C.F.Z), GM47969 (C.F.Z.), and MH00964 (C.F.Z.); and by a grant from the Bantly Foundation (C.F.Z.). We thank Drs. Jim Huettner, Joe Henry Steinbach, and Chris Lingle for advice on the NMDA receptor experiments and Ann Benz for assistance with the primary cultures.

Correspondence should be addressed to Dr. Steven Mennerick, Department of Psychiatry, Washington University School of Medicine, 4940 Children's Place, St. Louis, MO 63110.

Copyright (C) 1998 Society for Neuroscience $\quad 0270-6474 / 98 / 189716-11 \$ 05.00 / 0$ lar concentration for anesthesia in $50 \%$ of subjects (MAC) (Gonsowski and Eger, 1994). Because of its low potency, $\mathrm{N}_{2} \mathrm{O}$ is often used in combination with other anesthetics.

In an initial study, we showed that $\mathrm{N}_{2} \mathrm{O}$ possesses several properties of a noncompetitive NMDA receptor antagonist, including the ability to protect brain tissue against excitotoxic damage, the ability to damage neurons in posterior cingulate and retrosplenial cortex, and the ability to block NMDA-gated currents in CNS neurons. In addition, $\mathrm{N}_{2} \mathrm{O}$ weakly potentiates GABAR currents (Dzoljic and Duiijn, 1998; Jevtovic-Todorovic et al., 1998). A complete understanding of $\mathrm{N}_{2} \mathrm{O}$ actions requires an analysis of effects on neural communication, in which potential presynaptic and postsynaptic contributions can be assessed. To increase understanding of the mechanisms of $\mathrm{N}_{2} \mathrm{O}$ actions, we explored in the current study the actions of $\mathrm{N}_{2} \mathrm{O}$ on neurotransmission in a simple setting of rat hippocampal microcultures (Segal and Furshpan, 1990). Solitary neurons grown in synaptic isolation in microcultures form autaptic (self-synaptic) connections (Bekkers and Stevens, 1991; Segal, 1991), thereby allowing the exploration of $\mathrm{N}_{2} \mathrm{O}$ synaptic actions in an environment free of many complicating variables, such as feedback inhibition and other network properties associated with more intact preparations.

\section{MATERIALS AND METHODS}

Hippocampal cultures. Hippocampal cells were prepared from 1-3 d postnatal Sprague Dawley rats. Slices of hippocampus 500-800 $\mu \mathrm{m}$ thick were digested with $1 \mathrm{mg} / \mathrm{ml}$ papain in oxygenated Leibovitz's L-15 medium. Digested slices were mechanically triturated in modified Eagle's medium containing 5\% horse serum, 5\% fetal calf serum, $17 \mathrm{~mm}$ D-glucose, $400 \mu \mathrm{M}$ glutamine, $50 \mathrm{U} / \mathrm{ml}$ penicillin, and $50 \mu \mathrm{g} / \mathrm{ml}$ strepto- 
mycin. Cells $\left(75 / \mathrm{mm}^{2}\right)$ were plated onto plastic culture dishes coated with a layer of collagen microdots over a layer of dried $0.15 \%$ agarose (microcultures) as described previously (Mennerick et al., 1995). Cultures were treated with cytosine arabinoside $(10 \mu \mathrm{M})$ after $3 \mathrm{~d}$ in vitro and were used for experiments $1-16 \mathrm{~d}$ after plating.

Electrophysiology. The extracellular bath solution for synaptic physiology contained (in mM): $\mathrm{NaCl} 140, \mathrm{KCl} 4.0, \mathrm{CaCl}_{2} 2.0, \mathrm{MgCl}_{2} 1.0$, and HEPES 10. For experiments examining isolated NMDA receptormediated (NMDAR) excitatory autaptic currents (EACs), 2,3dihydroxy-6-nitro-7-sulfamoylbenzo(F)quinoxaline (NBQX; $1 \mu \mathrm{M}$ ), glycine $(10 \mu \mathrm{M})$, and bicuculline $(25 \mu \mathrm{M})$ were added to the bath, and $\mathrm{Mg}^{2+}$ was removed from the bath. For examination of AMPA receptormediated (AMPAR) EACs, D-2-amino-5-phosphonovalerate (D-APV; $25 \mu \mathrm{M})$ and bicuculline $(25 \mu \mathrm{M})$ were added to the bath. For examination of inhibitory autaptic currents (IACs), NBQX (1 $\mu \mathrm{M})$ and D-APV (50 $\mu \mathrm{M})$ were added. For examination of miniature EPSCs (mEPSCs), tetrodotoxin $(500 \mathrm{nM}), \mathrm{D}-\mathrm{APV}(25 \mu \mathrm{M})$, and bicuculline $(25 \mu \mathrm{M})$ were included in the bath. In experiments in which currents were induced by exogenous NMDA, the extracellular solution contained no added $\mathrm{Mg}^{2+}$ and contained reduced $\mathrm{Ca}^{2+}(0.1-0.5 \mathrm{~mm})$ to diminish calciumdependent fade of NMDA-induced currents (Mayer and Westbrook, 1985; Zorumski et al., 1989; Legendre et al., 1993). For examination of high-voltage-activated (HVA) calcium currents, $5 \mathrm{~mm} \mathrm{BaCl}_{2}$ replaced $\mathrm{CaCl}_{2}$ and $\mathrm{MgCl}_{2}$ and served as the charge carrier. Additionally, $1 \mu \mathrm{M}$ tetrodotoxin was present in the bath. Calcium currents were leak subtracted using a $\mathrm{P} / 5$ (subpulse) protocol. Voltage pulses from -70 to -10 $\mathrm{mV}$ delivered every $20 \mathrm{sec}$ were used to elicit HVA calcium currents.

For addition of gas, the extracellular solution was bubbled with air or $\mathrm{N}_{2} \mathrm{O} / \mathrm{O}_{2}$ mixtures using a bubbling stone. The bubbling container was sealed with Parafilm punctured with a small escape hole. The solution was equilibrated with gas for at least $30 \mathrm{~min}$, at which time gasequilibrated solutions were drawn into a closed glass syringe. The syringe served as a solution reservoir for a gravity-driven local perfusion system consisting of glass tubes connecting the reservoirs with a multibarrel pipette (List Electronic, Darmstadt, Germany). The common tip of the multibarrel pipette was placed $400 \mu \mathrm{m}$ from the recorded cell. Solution flow rates were $0.8-1.5 \mathrm{ml} / \mathrm{min}$. The slower flow rates were used for synaptic experiments; faster flow rates (attained with larger-bore glass connecting tubes) were used for exogenous applications. Based on junction-current measurements using solutions of different chloride concentrations, rise times of solution exchanges with the faster flow rates were $<30 \mathrm{msec}(10-90 \%$ rise) at the tip of an open recording pipette. For most experiments $80 \% \mathrm{~N}_{2} \mathrm{O} / 20 \% \mathrm{O}_{2}$ was used so that bottled air $(80 \%$ $\mathrm{N}_{2} / 20 \% \mathrm{O}_{2}$ ) could be used as a control.

The whole-cell recording pipette solution for studies of EACs contained (in mM): potassium gluconate $130, \mathrm{NaCl} 4.0, \mathrm{CaCl}_{2} 0.5$, EGTA 5.0, HEPES 10, $\operatorname{MgATP}_{2} 2.0$, and GTP 0.5 . For study of IACs, gluconate was replaced with chloride. For studies of responses to exogenous glutamate receptor agonists and for studies of mEPSCs, cesium methanesulfonate replaced potassium gluconate. For study of the voltage dependence of NMDA-receptor blockade, cesium chloride or choline chloride replaced potassium gluconate in the patch-pipette solution. The $\mathrm{pH}$ of solutions was adjusted to 7.25 .

For evoked synaptic responses, whole-cell, voltage-clamp recordings of autaptic currents were performed from solitary neurons using pipettes with an open-tip resistance of 2-5 M $\Omega$ and with series resistance compensated $90-100 \%$ using the compensation circuitry of an Axopatch 1-D amplifier (Axon Instruments, Foster City, CA). Neurons were stimulated with a brief $(1.5 \mathrm{msec})$ voltage-command pulse to $0 \mathrm{mV}$ from a holding potential of $-70 \mathrm{mV}$. Successive sweeps were triggered at intervals of $\geq 20 \mathrm{sec}$ to allow recovery from short-term depression and facilitation. Paired-pulse stimuli were delivered at $100 \mathrm{msec}$ intervals for EACs and $500 \mathrm{msec}$ intervals for IACs to allow conditioning responses to decay before delivery of a test stimulus. Averages of two to five sweeps in each condition were used for display and analysis. For miniature synaptic currents and exogenous currents, experiments were not limited to solitary-neuron microcultures, and series-resistance compensation was usually not used to achieve the lowest background noise levels possible. EAC decays were fit with a single exponential or biexponential function, generated from a Chebychev-transform algorithm (Pclamp 6.0; Axon Instruments). Unless otherwise indicated, results are presented as mean $\pm \mathrm{SE}$.

\section{RESULTS}

\section{Effect of $\mathrm{N}_{\mathbf{2}} \mathrm{O}$ on NMDAR EPSCs}

Because we showed previously that $\mathrm{N}_{2} \mathrm{O}$ blocks NMDAR currents in hippocampal neurons, we first explored the effect of $\mathrm{N}_{2} \mathrm{O}$ on NMDAR synaptic currents in hippocampal microcultures. We found that a subanesthetic concentration of $80 \%$ (volume percent) $\mathrm{N}_{2} \mathrm{O}$ applied to isolated microculture neurons inhibited peak NMDAR EACs by $49 \pm 6 \%(n=6)$ compared with control responses $(-1314 \pm 317 \mathrm{pA})$ examined in extracellular saline bubbled with air. The degree of synaptic blockade was similar to that observed with exogenous applications of NMDA (JevtovicTodorovic et al., 1998) (see below).

NMDAR EACs in microcultures decay with a biexponential time course (Clements et al., 1992). In the present experiment, control EACs decayed with time constants of $89.5 \pm 4.6$ and $491 \pm 16 \mathrm{msec}$, with the fast component representing $53 \pm 3 \%$ of the initial amplitude of the EAC (Fig. 1B). The time course of NMDAR EACs was not significantly affected by the application of $80 \% \mathrm{~N}_{2} \mathrm{O}$ (Fig. 1A,B). The lack of $\mathrm{N}_{2} \mathrm{O}$ effect on NMDAR EAC time course has interesting implications for the mechanism of action of $\mathrm{N}_{2} \mathrm{O}$. Ketamine, another anesthetic known to inhibit NMDA receptor function, is a slowly dissociating antagonist that requires channel opening to inhibit NMDA receptors (MacDonald et al., 1987). When we examined the effect of 5-10 $\mu \mathrm{M}$ ketamine, we found a degree of peak NMDAR EAC inhibition similar to that induced by $80 \% \mathrm{~N}_{2} \mathrm{O}$ (Fig. $1 A, C ; 45 \pm 4 \%$ depression with baseline amplitudes of $-1545 \pm 248 \mathrm{pA} ; n=5$ ). However, in contrast to $\mathrm{N}_{2} \mathrm{O}$, ketamine also significantly decreased the decay time of the NMDAR EAC. The decrease in decay time in the presence of ketamine was expressed as a decrease in both the fast and slow time constants of decay as well as an increase in the relative amplitude of the fast component of decay (Fig. 1D). These effects of ketamine are similar to the effects of MK-801 (Rosenmund et al., 1993) at NMDA receptors and to the actions of slowly dissociating barbiturates acting on neuromuscular endplate currents (Adams, 1976).

In contrast to the actions of ketamine and of $\mathrm{N}_{2} \mathrm{O}$ on NMDAR EACs, classical open-channel blockers, like procaine or methyprylone, acting at neuromuscular nicotinic receptors prolong the late phase of endplate currents (Kordas, 1970; Adams, 1976) by increasing the burst duration of channels (Neher and Steinbach, 1978). Our data suggest that $\mathrm{N}_{2} \mathrm{O}$ acts neither like a classical open-channel blocker nor like a use-dependent, slowly reversible channel blocker. As a representative of another class of NMDA channel blockers, we examined the effects of the noncompetitive antagonist $\mathrm{Mg}^{2+}$. At a concentration of $15 \mu \mathrm{M}$, a concentration lower than that at which presynaptic effects of $\mathrm{Mg}^{2+}$ are observed (Tong and Jahr, 1994a), $\mathrm{Mg}^{2+}$ occluded peak NMDAR EACs by an amount similar to that obtained with ketamine and $\mathrm{N}_{2} \mathrm{O}$ (Fig. $1 E$ ). Like $\mathrm{N}_{2} \mathrm{O}, \mathrm{Mg}^{2+}$ had no detectable effect on the EAC decay (Fig. $1 F$ ). These effects of $\mathrm{Mg}^{2+}$ are consistent with the rapid block by $\mathrm{Mg}^{2+}$ of NMDA receptor channels, the ability of NMDA channels to close with $\mathrm{Mg}^{2+}$ still bound, and the lack of prolongation of channel burst duration (Nowak et al., 1984). These results suggest that if $\mathrm{N}_{2} \mathrm{O}$ acts via a channel block mechanism, the mechanism is unlikely that of a classical open-channel blocker or of a slowly dissociating open-channel blocker like ketamine. 
A

Figure 1. Effect of $\mathrm{N}_{2} \mathrm{O}$ and noncompetitive NMDA receptor antagonists on NMDAR EACs. $A$, Effect of $\mathrm{N}_{2} \mathrm{O}$ on peak amplitude and on time course of NMDAR EACs is shown. Left, The effect of $\mathrm{N}_{2} \mathrm{O}$ on peak NMDAR responses. Control responses were obtained in the presence of extracellular solution bubbled with air and exhibit the larger peak current. Right, The EAC in the presence of $\mathrm{N}_{2} \mathrm{O}$ scaled to the peak NMDAR response in the absence of $\mathrm{N}_{2} \mathrm{O}$. No effect of $\mathrm{N}_{2} \mathrm{O}$ could be detected on the time course of NMDAR EACs. B, Bar graphs summarize the effect of $\mathrm{N}_{2} \mathrm{O}$ (hashed bars) on the biexponential decay of NMDAR EACs. Open bars represent EACs in the presence of air. No significant difference was detected either in the time constant or in the relative contribution of the two components to the total amplitude $(n=6$; paired $t$ test). $C$, Effect of $5 \mu \mathrm{M}$ ketamine on NMDAR EACs is shown. Note the speeding of the NMDAR EAC apparent in the scaled traces. $D$, Ketamine induced speeding of both the fast and slow time constant of decay and an increase in the relative contribution of the fast component (an asterisk indicates $p<0.02 ; n=$ 5 ; paired $t$ test). $E, F, \mathrm{Mg}^{2+}(15 \mu \mathrm{M})$ has effects on peak and time course similar to those of $\mathrm{N}_{2} \mathrm{O}$. No significant effect on time course was detected in six cells. For synaptic current traces in this and subsequent figures, stimulus transients have been partially blanked and truncated for clarity of presentation.
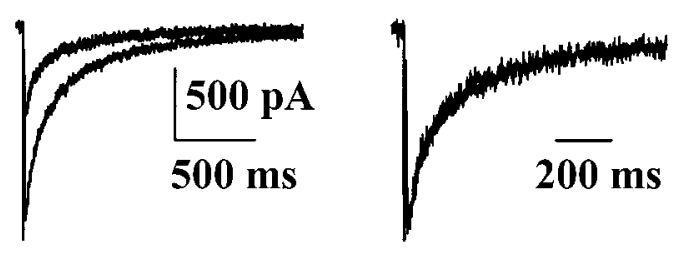

B
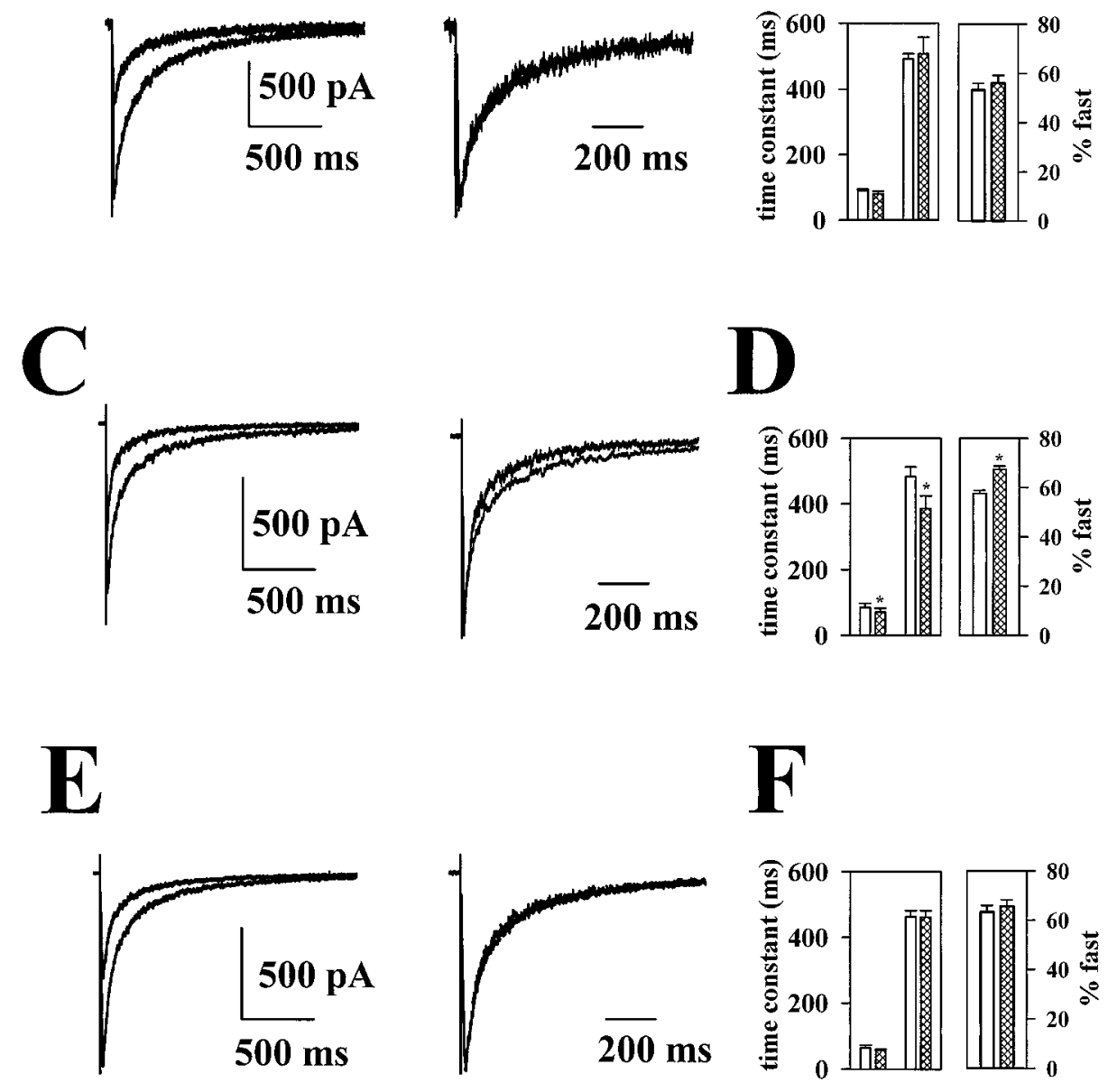

$\frac{5}{2}$

$\stackrel{5}{5}$

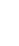



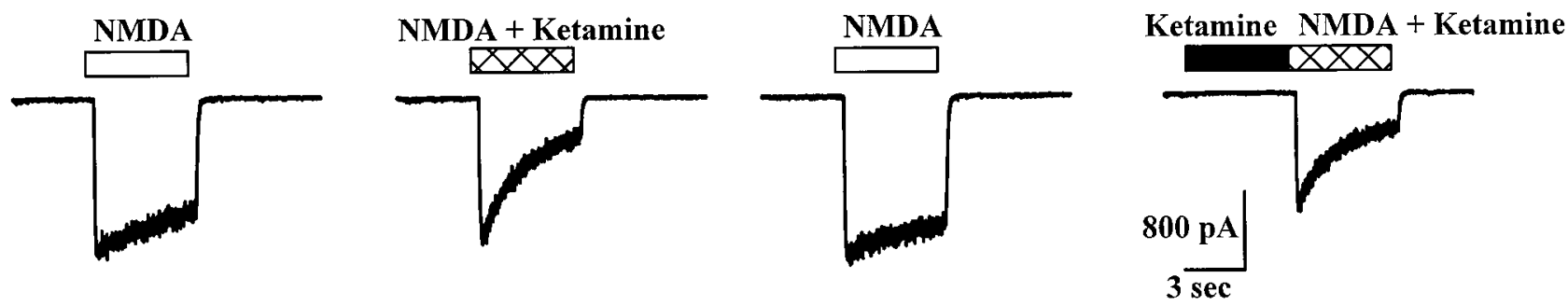

B
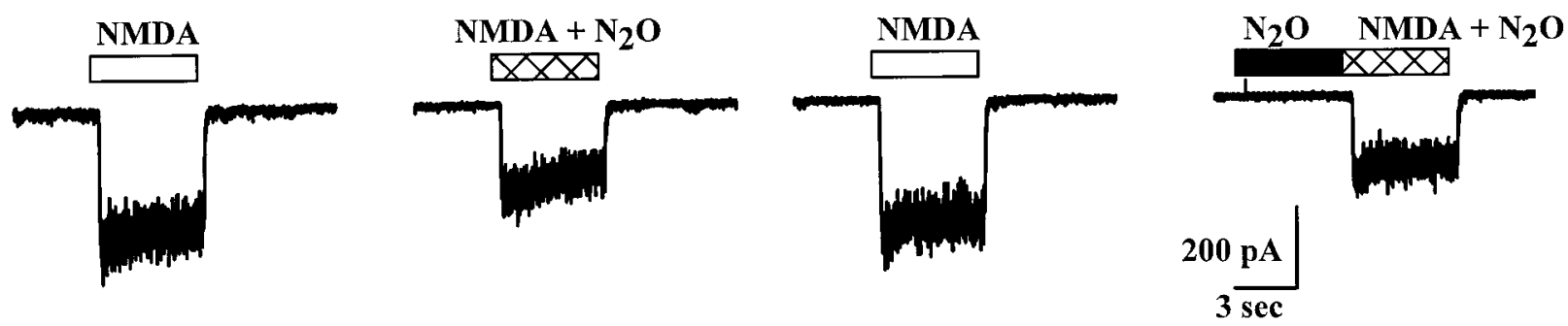

Figure 2. $\mathrm{N}_{2} \mathrm{O}$ exhibits rapid block of NMDAR currents. $A$, Responses to $20 \mu \mathrm{M}$ NMDA $\left(0.5 \mathrm{mM} \mathrm{Ca}^{2+}\right.$ and nominally $0 \mathrm{mM} \mathrm{Mg}^{2+}$ present in the extracellular recording solution) in the presence or absence of $3 \mu \mathrm{M}$ ketamine. The horizontal bars over the traces indicate the timing of NMDA and ketamine applications. $B$, The same application protocol performed on another cell using $\mathrm{N}_{2} \mathrm{O}$ as the antagonist. Note the rapid development of block with coapplication of agonist and antagonist.

To investigate the possibility that this mechanism might underlie the apparent voltage dependence of $\mathrm{N}_{2} \mathrm{O}$, we used a pipette solution of either cesium chloride or choline chloride and examined the effect of $\mathrm{N}_{2} \mathrm{O}$ on NMDA responses. As expected, when choline was used as the main intracellular cation, reversal potentials for NMDA currents were shifted to approximately $+50 \mathrm{mV}$ from the typical $0 \mathrm{mV}$ (data not shown). When examined at -30 $\mathrm{mV}, \mathrm{N}_{2} \mathrm{O}$ block of inward NMDA currents was not significantly different between cesium- and choline-loaded cells (Fig. 4A-C). However, when $5 \mu \mathrm{M}$ ketamine was used as an antagonist, blockade of NMDA currents at $-30 \mathrm{mV}$ was significantly enhanced in choline-loaded cells versus cesium-loaded cells (Fig. 4D-F). The blockade of NMDA currents by $\mathrm{Mg}^{2+}(15 \mu \mathrm{M})$ was also greater in choline-loaded cells than in cesium-loaded cells examined at the same membrane potential (Fig. 4G-I). These results suggest that enhancing the inward driving force on ions through NMDA receptors does not affect the degree of block by $\mathrm{N}_{2} \mathrm{O}$ and make it unlikely that the apparent voltage dependence of $\mathrm{N}_{2} \mathrm{O}$ blockade can be explained by an effect of current flow through the NMDA channel. On the other hand, current flow through the NMDA channel significantly interacts with ketamine and $\mathrm{Mg}^{2+}$ blockade, suggesting this mechanism plays a role in the apparent voltage dependence of ion channel block.

\section{Effect of $\mathrm{N}_{2} \mathrm{O}$ on AMPAR EACs and tests of presynaptic $\mathrm{N}_{2} \mathrm{O}$ effects}

We next examined the effect of $\mathrm{N}_{2} \mathrm{O}$ on AMPAR EACs in the presence of 25-50 $\mu \mathrm{M} \mathrm{D}-\mathrm{APV}$ and $1 \mathrm{mM} \mathrm{Mg}^{2+}$ to block the NMDAR component of EACs. AMPAR EACs were also inhib- ited by $\mathrm{N}_{2} \mathrm{O}$, but less than were NMDAR EACs (Fig. 5). The inhibition by $\mathrm{N}_{2} \mathrm{O}$ of both NMDAR and AMPAR EACs compared with air controls may suggest a presynaptic effect of $\mathrm{N}_{2} \mathrm{O}$ because AMPAR and NMDAR EACs are similarly affected by presynaptic manipulations (Tong and Jahr, 1994a). To determine whether the effects on AMPAR EACs were caused by presynaptic or postsynaptic effects of $\mathrm{N}_{2} \mathrm{O}$, we first examined paired-pulse modulation, a form of plasticity that is susceptible to presynaptic modulation both in situ and in microcultures (McNaughton, 1980; Mennerick and Zorumski, 1995). Previously, we found that many different presynaptic modulators alter the degree of paired-pulse depression of microculture AMPAR EACs (Mennerick and Zorumski, 1995). However, $\mathrm{N}_{2} \mathrm{O}$ failed to significantly change the degree of paired-pulse depression observed in response to paired stimulation delivered $100 \mathrm{msec}$ apart (Fig. 5C,D).

As another test for presynaptic effects of $\mathrm{N}_{2} \mathrm{O}$, we examined the frequency of AMPAR mEPSCs (recorded with $500 \mathrm{~nm}$ tetrodotoxin in the extracellular recording solution) in the presence of air and $\mathrm{N}_{2} \mathrm{O}$. In six neurons we could detect no change in mEPSC frequency with exchange of $\mathrm{N}_{2} \mathrm{O}$ for air in the extracellular bath $\left(1.1 \pm 0.7 \mathrm{~Hz}\right.$ in air; $1.1 \pm 0.6 \mathrm{~Hz}$ in $\mathrm{N}_{2} \mathrm{O}$; data not shown). However, we were also unable to detect a significant change in mEPSC amplitude in the presence of $\mathrm{N}_{2} \mathrm{O}$ in this experiment. For instance, in the cell with the highest frequency of mEPSCs, mEPSC peak amplitude was $-33.7 \pm 2.1 \mathrm{pA}$ in air $(n=118$ events) and $-36.1 \pm 1.9 \mathrm{pA}$ in $\mathrm{N}_{2} \mathrm{O}(n=146$ events; $p>0.4)$. Although this could represent a lack of postsynaptic effect, the negative result is more likely attributable to the small effect of 


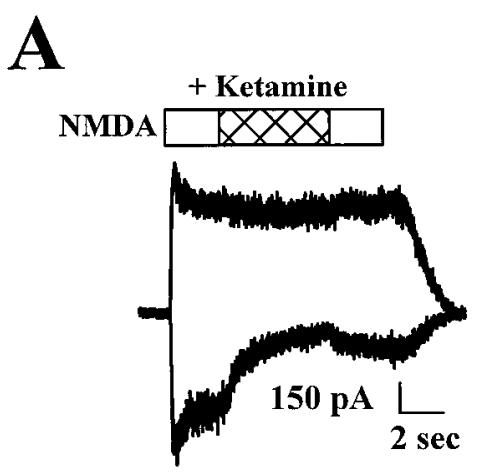

B
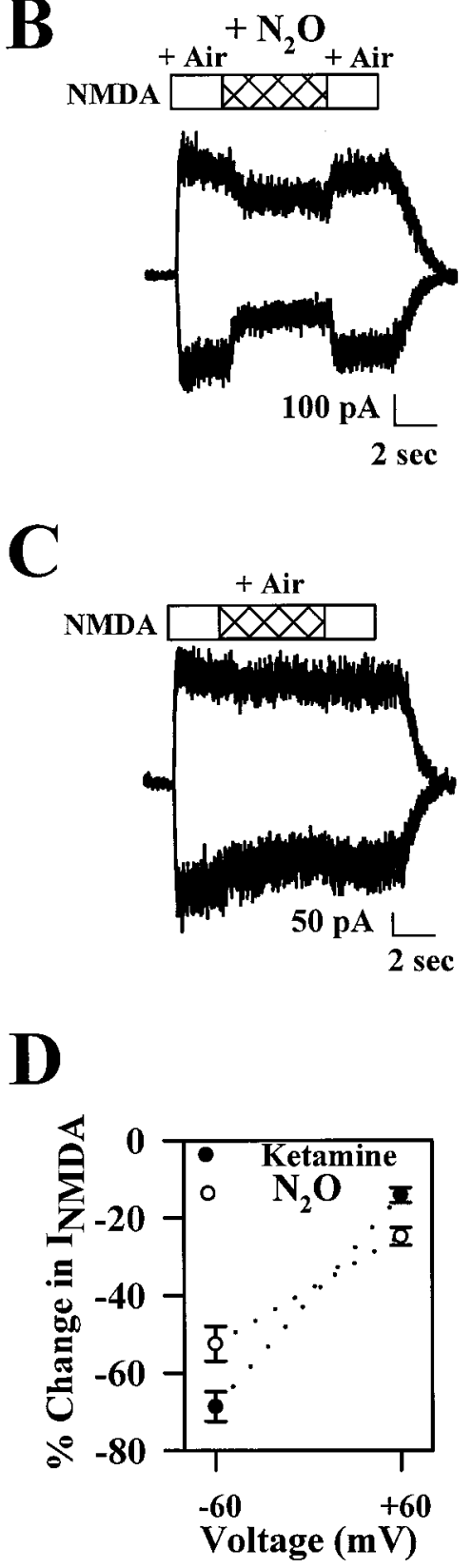

Figure 3. Voltage dependence of $\mathrm{N}_{2} \mathrm{O}$ and ketamine block of NMDA receptors. $A-C$, Raw traces at holding potentials of $-60 \mathrm{mV}$ (inward currents) and $+60 \mathrm{mV}$ (outward currents) exemplifying the effects of ketamine $(A), \mathrm{N}_{2} \mathrm{O}(B)$, and air $(C)$ on NMDAR currents. Baseline holding currents have been subtracted. The horizontal bars over the traces
$\mathrm{N}_{2} \mathrm{O}$ on peak synaptic responses coupled with the large variability in mEPSC amplitudes (Bekkers et al., 1990).

As a third experiment to determine whether $\mathrm{N}_{2} \mathrm{O}$ might have presynaptic effects, we examined effects on voltage-gated calcium currents in hippocampal neurons. Because a common target of many modulators of presynaptic function is HVA calcium channels (Miller, 1990; Wu and Saggau, 1997), we first examined the effect of $\mathrm{N}_{2} \mathrm{O}$ on HVA calcium current in hippocampal neurons. We found no reliable effect of $80 \% \mathrm{~N}_{2} \mathrm{O}$ on soma HVA currents in these cells compared with currents in the presence of air (98.7 $\pm 1.5 \%$ of control; control peak amplitude, $-327 \pm 74 \mathrm{pA}$; $n=5$; Fig. 6). Because of the difficulty of spatially voltageclamping cultured neurons, we also examined HVA calcium currents in acutely dissociated rat dorsal root ganglia neurons, which do not have extensive processes. These results also showed no effect of $\mathrm{N}_{2} \mathrm{O}$ on HVA currents (data not shown).

\section{Effect of $\mathrm{N}_{2} \mathrm{O}$ on exogenously activated AMPAR currents}

The above experiments suggest that presynaptic depression does not contribute to the depression of excitatory synaptic transmission. Therefore, we designed experiments to assess more directly the possibility of postsynaptic modulation of AMPA glutamate receptors by $\mathrm{N}_{2} \mathrm{O}$. We examined the effect of $\mathrm{N}_{2} \mathrm{O}$ on currents elicited by kainic acid, a weakly desensitizing agonist at AMPA receptors. Steady-state responses to $50 \mu \mathrm{M}$ kainate averaged $-568 \pm 146 \mathrm{pA}$ in the presence of air and were inhibited by $32 \pm$ $2 \%$ at $-60 \mathrm{mV}(n=10)$. With a higher concentration of agonist ( $1 \mathrm{~mm} \mathrm{KA})$, the degree of blockade was similar $(-29 \pm 2 \%$ change; $n=11$; data not shown). When blockade at -60 and +60 $\mathrm{mV}$ was compared, a similar degree of antagonism was observed at both potentials ( $p>0.15$, paired $t$ test; Fig. 7). These results suggest that like blockade of NMDA receptors, $\mathrm{N}_{2} \mathrm{O}$ blockade of AMPA receptors appears noncompetitive. However, unlike the blockade of NMDA receptors, there is no detectable voltage dependence to the block. The effects observed are unlikely to be caused by blockade of high-affinity kainate receptors, because these receptors are rapidly desensitized with the drug application protocols used (Wilding and Huettner, 1997). Also, at the high concentration of kainate, mostly AMPA receptors are activated in hippocampal cells because of the greater numbers of these receptors. Therefore, the similar degree of block at the two concentrations suggests that blockade is primarily of postsynaptic AMPA receptors.

Tests of $\mathrm{N}_{2} \mathrm{O}$ interaction with presynaptic metabotropic receptors and with glutamate transporters

Because the present results show that $\mathrm{N}_{2} \mathrm{O}$ interacts with both NMDA and non-NMDA subtypes of ionotropic glutamate recep-

$\leftarrow$

indicate the timing of drug applications. $D$, Summary data showing fractional inhibition of steady-state NMDAR currents by ketamine $(5 \mu \mathrm{M}$; closed circles) or $\mathrm{N}_{2} \mathrm{O}(80 \%$; open circles $)$ at -60 and $+60 \mathrm{mV}$. Collapsed across voltages, there was no significant difference between antagonists (at the concentrations used) in the amount of block [repeated measures ANOVA with drug as a between-cell variable and voltage as a within-cell variable, $F_{(1,17)}=0.66 ; p=0.42 ; n=9$ ketamine and $10 \mathrm{~N}_{2} \mathrm{O}$ cells]. There was significant voltage dependence to the degree of inhibition $\left[F_{(1,17)}=\right.$ $156.4 ; p<0.001]$. Post hoc comparisons revealed that both drugs exhibited significant voltage dependence ( $p<0.001$ for both drugs, paired $t$ test). However, there was also a significant interaction between antagonist and voltage $\left[F_{(1,17)}=16.7 ; p=0.001\right]$, indicating that ketamine exhibits significantly stronger voltage dependence than $\mathrm{N}_{2} \mathrm{O}$ exhibits. 


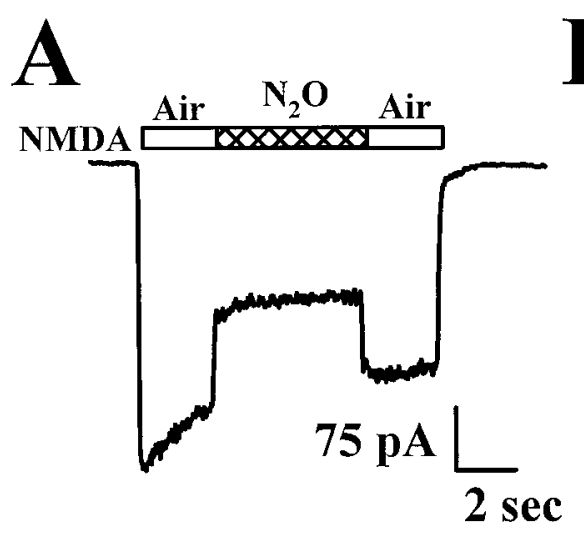

Cesium
B

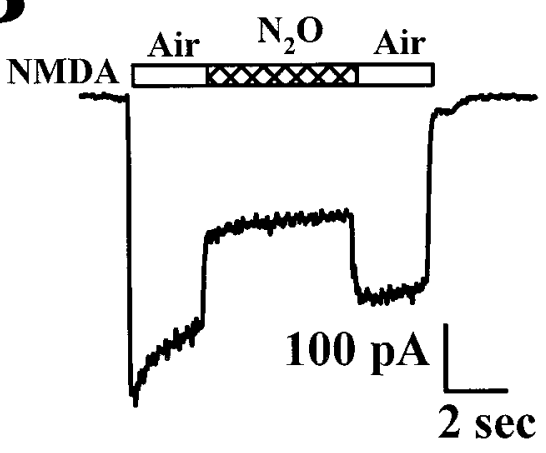

Choline

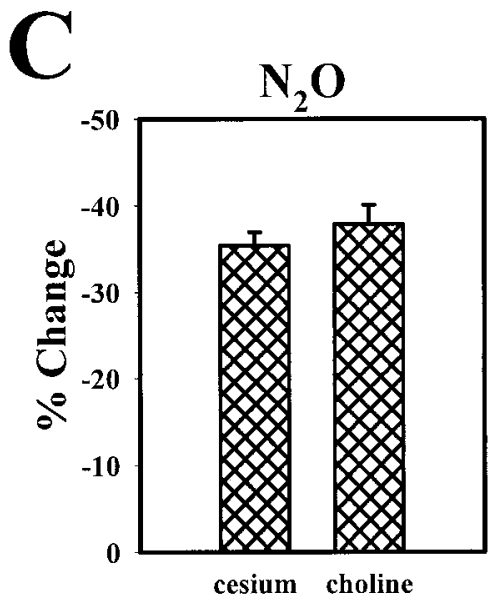

F

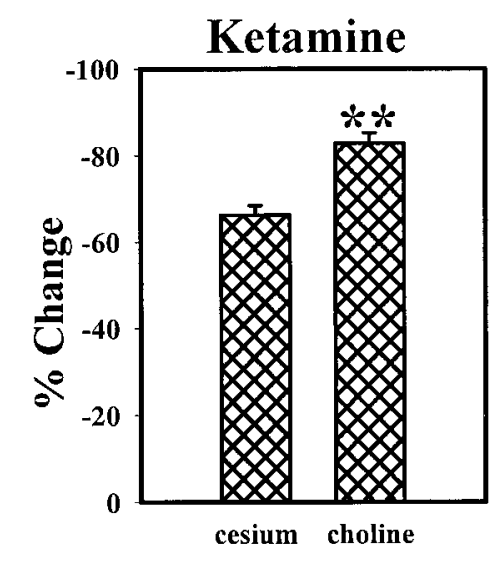

I

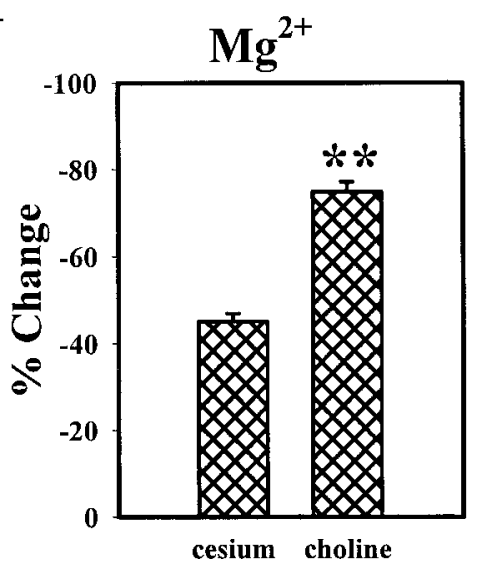

Figure 4. Effect of changing the reversal potential of the NMDAR current on blockade of NMDAR responses. $A, B$, Raw traces from two different cells illustrate the $\mathrm{N}_{2} \mathrm{O}$ block with cesium loading $(A)$ and choline loading $(B)$. The horizontal bars over the traces indicate the timing of drug applications. $C$, At a holding potential of $-30 \mathrm{mV}$, the degree of $\mathrm{N}_{2} \mathrm{O}$ block in cesium-loaded cells was not significantly different from the degree of block in cells loaded with choline ( $p>0.3$, unpaired $t$ test; $n=14$ cesium- and 11 choline-loaded cells). Choline loading changed the reversal potential of currents from $\sim 0$ to approximately $+50 \mathrm{mV}$. $D, E$, Raw traces from two different cells illustrate the ketamine block in cesium- versus choline-filled cells. $F$, At a holding potential of $-30 \mathrm{mV}$, the degree of ketamine $(5 \mu \mathrm{m})$ block in choline-loaded cells was significantly greater than the block in cesium-loaded cells ( $p<0.001$, unpaired $t$ test; $n=7$ cesium- and 6 choline-loaded cells). $G-I$, A protocol similar to that shown in $A-C$ and $D-F$ was used except that $\mathrm{Mg}^{2+}$ was used as the antagonist and the holding potential was $-60 \mathrm{mV}$. Raw traces in all panels have been filtered at $10 \mathrm{~Hz}$ for display. 
A
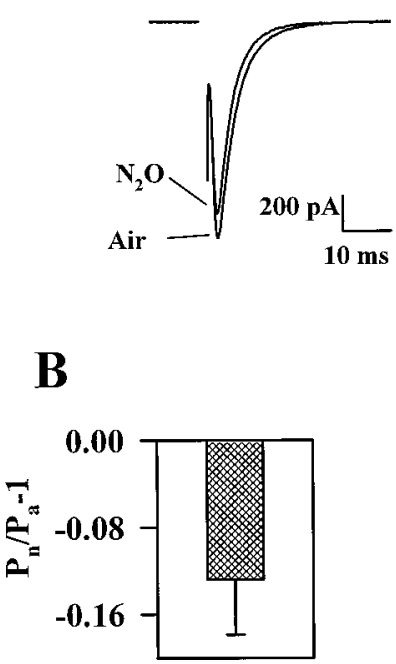

C

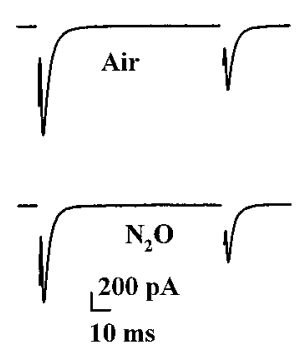

D

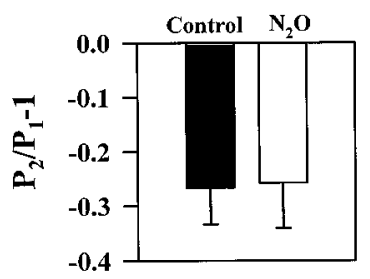

Figure 5. Effect of $\mathrm{N}_{2} \mathrm{O}$ on AMPAR EACs. $A$, Averaged waveforms of interleaved AMPAR EACs in the presence of air or $\mathrm{N}_{2} \mathrm{O}$ are shown. $B$, Average depression induced by $80 \% \mathrm{~N}_{2} \mathrm{O}$ on peak AMPAR EACs $(n=$ $8)$ is shown. Depression was calculated as: $\left(P_{n} / P_{a}\right)-1$, where $P_{n}$ is the peak response in the presence of $\mathrm{N}_{2} \mathrm{O}$, and $P_{a}$ is the peak response in the presence of air. $C, D$, Paired-pulse depression of AMPAR EACs was unaffected by $\mathrm{N}_{2} \mathrm{O}$. $C$, Example currents are from the same cell shown in $A$. Paired-pulse interval was $100 \mathrm{msec}$. $D$, The degree of paired-pulse modulation was calculated by subtracting 1 from the test peak $\left(P_{2}\right) /$ conditioning peak $\left(P_{1}\right)$ ratio $\left(P_{2} / P_{1}\right)$. Therefore, depression yields negative values, and facilitation yields positive values.

tors, we also assessed whether $\mathrm{N}_{2} \mathrm{O}$ targets presynaptic metabotropic glutamate receptors. We showed previously that activation of metabotropic receptors causes presynaptic depression at microculture autaptic synapses (Mennerick and Zorumski, 1995). Similarly, in the present study we found that the combination of $100 \mu \mathrm{M} 1 S, 3 R$-1-aminocyclopentane-1,3-dicarboxylic acid (1S,3RACPD) plus $100 \mu \mathrm{M}$ L-AP-4 to activate groups I, II, and III metabotropic receptors (Conn and Pin, 1997) depressed AMPAR EACs by $36 \pm 9 \%$ from a baseline amplitude of $-3379 \pm 859 \mathrm{pA}$ (all responses recorded in the presence of air; $n=7$ ). The effect of $\mathrm{N}_{2} \mathrm{O}$ on peak AMPAR EAC was similar in the absence or presence of metabotropic agonists $\left(-13 \pm 2 \% \quad \mathrm{~N}_{2} \mathrm{O}\right.$-induced change relative to responses in the absence of metabotropic agonists; $-11 \pm 2 \%$ change relative to responses in the presence of metabotropic agonists; $n=8$; Fig. 8). From this experiment, we conclude that $\mathrm{N}_{2} \mathrm{O}$ does not interact with the metabotropic receptors involved in mediating depression of synaptic responses. We cannot exclude an effect of $\mathrm{N}_{2} \mathrm{O}$ on other physiological effects of metabotropic receptors, such as phosphoinositide hydrolysis.

Glutamate transporters are another class of plasma membrane glutamate-binding proteins that might be a target for $\mathrm{N}_{2} \mathrm{O}$ actions. Glutamate transporters in situ and in culture rapidly bind glutamate after synaptic release (Mennerick and Zorumski, 1994; Tong and Jahr, 1994b). Under certain conditions, transport inhibitors can influence the peak glutamate concentration obtained (Tong and Jahr, 1994b) or increase the effective lifetime of glutamate acting at postsynaptic receptors (Mennerick and Zorumski, 1994). Additionally, glutamate transporters may be the target of other volatile anesthetics (Hirofumi et al., 1997). For these reasons, we directly tested the possibility that glutamate transporters are a target of $\mathrm{N}_{2} \mathrm{O}$ actions by exploiting the elec-

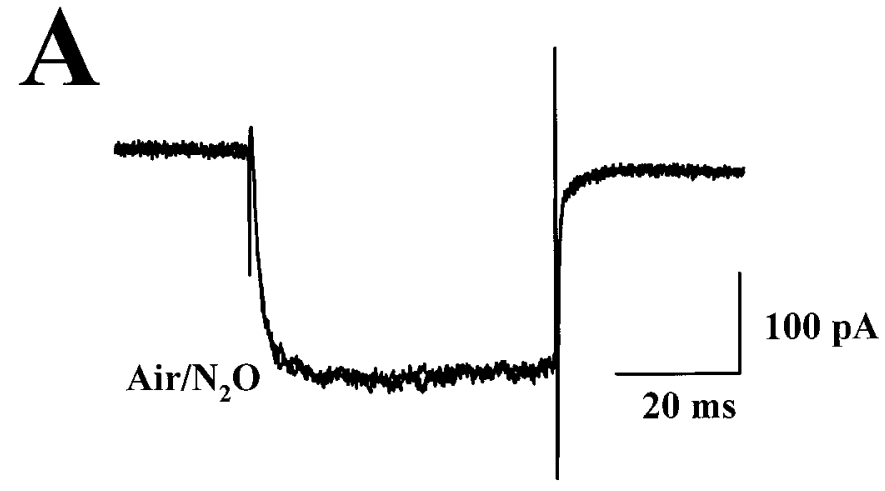

B

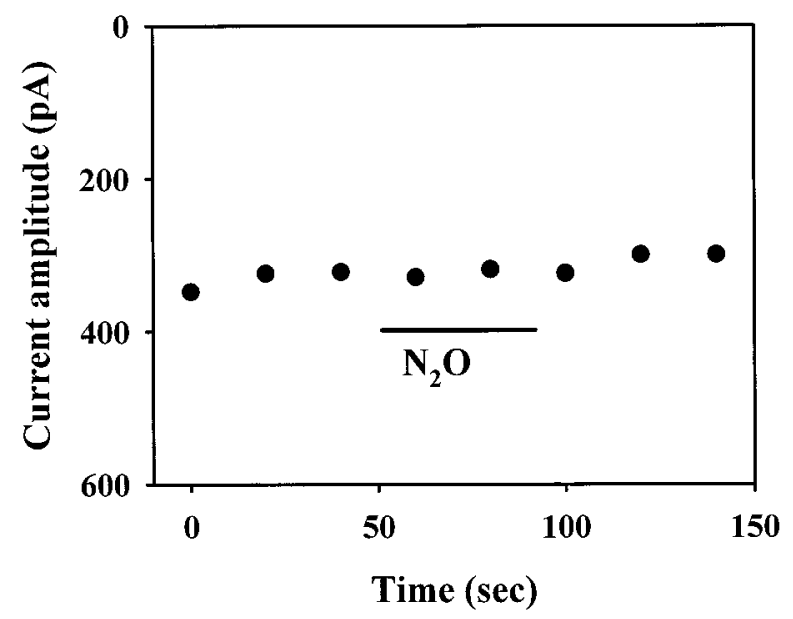

Figure 6. Effect of $\mathrm{N}_{2} \mathrm{O}$ on $\mathrm{HVA}$ calcium currents in hippocampal neurons. $A$, Superimposed leak-subtracted traces from a hippocampal neuron in the presence of air and $80 \% \mathrm{~N}_{2} \mathrm{O}$. Voltage pulses from -70 to $-10 \mathrm{mV}$ were used to elicit the currents; $5 \mathrm{mM} \mathrm{BaCl}_{2}$ was used as the charge carrier as detailed in Materials and Methods. B, Time course plot showing the lack of effect of $\mathrm{N}_{2} \mathrm{O}$ on the amplitude of leak-subtracted barium current in another neuron.

trogenicity of glutamate transporters (Brew and Attwell, 1987). We examined the effect of $\mathrm{N}_{2} \mathrm{O}$ on D-aspartate currents elicited from microculture glia filled with a potassium gluconate solution. Under the conditions of this experiment, the current generated by D-aspartate application should result from the electrogenic transport current produced by the net influx of positive charge on each transporter cycle but not from the recently described anion conductance also gated by glutamate transporter activation (Wadiche et al., 1995). In four glial cells, D-aspartate currents averaged $-45.5 \pm 21 \mathrm{pA}$. We observed little change in the D-aspartate current with coapplication of $80 \% \mathrm{~N}_{2} \mathrm{O}(+8 \pm 2 \%$ change compared with the current with D-aspartate in the presence of air). In two additional cells there was an apparent enhancement of the glutamate transporter current when D-aspartate and $\mathrm{N}_{2} \mathrm{O}$ were coapplied (the trace shown in Fig. 9 is an example of a modest enhancement). However, this apparent change was unrelated to an effect on glutamate transporter currents, because the current was elicited by $\mathrm{N}_{2} \mathrm{O}$ alone in the absence of D-aspartate (data not shown) and was present in one cell despite an undetectable D-aspartate current. Furthermore, the response to $\mathrm{N}_{2} \mathrm{O}$ alone was 


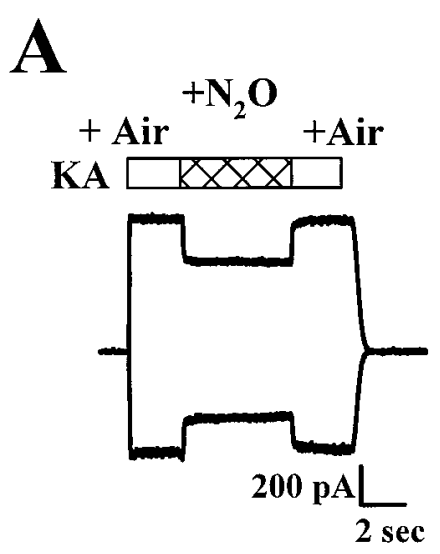

B

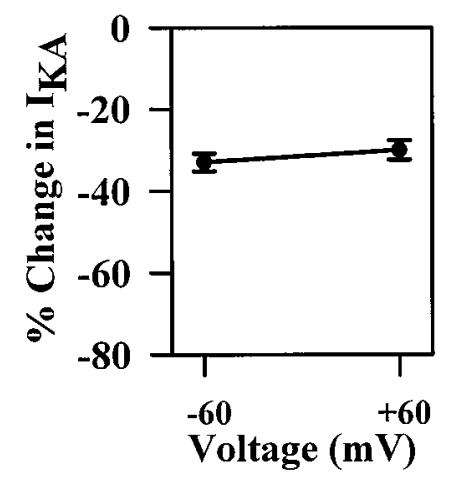

Figure 7. Effect of $\mathrm{N}_{2} \mathrm{O}$ on kainic acid $(K A)$-induced currents. $A$, Exemplar traces obtained from one neuron at $-60 \mathrm{mV}$ (inward current trace) and at $+60 \mathrm{mV}$ (outward current trace). Drug applications were made during the periods indicated by the horizontal bars. $B$, Summary of the effect of $\mathrm{N}_{2} \mathrm{O}$ on the responses to $50 \mu \mathrm{M} \mathrm{KA}$ at -60 and at $+60 \mathrm{mV}$ $(n=10)$.

not observed in all glial cells in which transporter currents were detected. Finally, transporter currents under the present conditions reverse direction at potentials more positive than $+50 \mathrm{mV}$ (Brew and Attwell, 1987), whereas the $\mathrm{N}_{2} \mathrm{O}$-induced glial current reversed direction near $-70 \mathrm{mV}$ (data not shown). Because of its small amplitude and variability, the direct effect of $\mathrm{N}_{2} \mathrm{O}$ on glial membrane conductance was not studied further in the present work.

\section{$\mathrm{N}_{2} \mathrm{O}$ and GABAR IACs}

Approximately $50 \%$ of the neurons in postnatally derived hippocampal microcultures are GABAergic (Bekkers and Stevens, 1991; Segal, 1991). We studied the effect of $\mathrm{N}_{2} \mathrm{O}$ on IACs by replacing gluconate in the whole-cell pipette with chloride to cause IACs to appear as inward currents at $-70 \mathrm{mV}$. Consistent with weak effects of $\mathrm{N}_{2} \mathrm{O}$ on $\mathrm{GABA}_{\mathrm{A}}$ receptor-mediated currents in response to exogenous GABA (Dzoljic and Duiijn, 1998; Jevtovic-Todorovic et al., 1998), we observed small effects of $\mathrm{N}_{2} \mathrm{O}$ on GABAR IACs. Peak GABAR IACs were not affected by $80 \% \mathrm{~N}_{2} \mathrm{O}(2 \pm 3 \%$ potentiation compared with air; $n=21)$. Measured using the $10-90 \%$ decay time to quantify the IAC time course, IAC decays were variably affected, ranging from no effect to $50 \%$ prolongation ( $n=21$; Fig. 10$)$. Overall, $\mathrm{N}_{2} \mathrm{O}$ resulted in a $15 \pm 5 \%$ increase in the IAC charge transfer $(n=21)$. As a

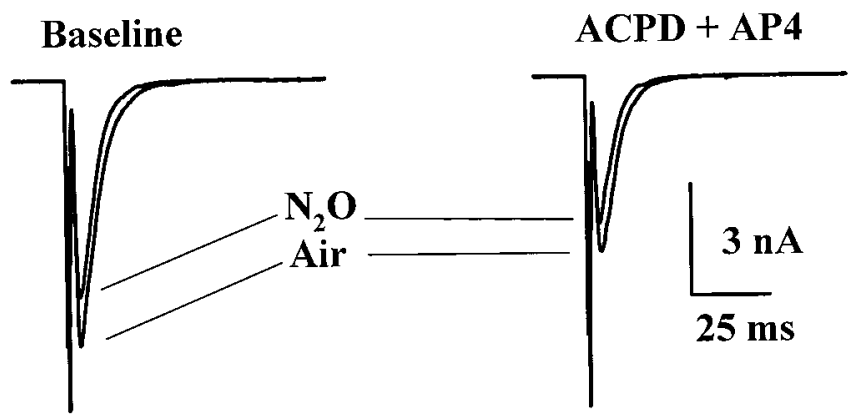

Figure 8. $\quad \mathrm{N}_{2} \mathrm{O}$ does not interact with metabotropic glutamate receptorinduced synaptic depression. Left, The effect of $\mathrm{N}_{2} \mathrm{O}$ on the AMPAR EAC obtained in the absence of metabotropic agonists (air vs $\mathrm{N}_{2} \mathrm{O}$ ). Right, The effects of $\mathrm{N}_{2} \mathrm{O}$ after the addition of $100 \mu \mathrm{M} 1 S, 3 R$-ACPD plus $100 \mu \mathrm{M}$ L-AP-4, which depressed transmission.

comparison we used pentobarbital, an anesthetic known to potentiate GABAergic transmission (Franks and Lieb, 1994). Because $80 \% \mathrm{~N}_{2} \mathrm{O}$ is approximately one-half the MAC required to produce anesthesia in rats (Jevtovic-Todorovic et al., 1998), we used $25 \mu \mathrm{M}$ pentobarbital, which should represent an anesthetic concentration equivalent to $80 \% \mathrm{~N}_{2} \mathrm{O}$ (Franks and Lieb, 1994), as a comparison. Slowing of IAC decays was much more pronounced with pentobarbital compared with $\mathrm{N}_{2} \mathrm{O}$; pentobarbital treatment increased the IAC charge transfer by $86 \pm 13 \%$, with little effect on IAC peak amplitude ( $8 \pm 7 \%$ change; $n=4$; Fig. $10 A, B)$. Paired-pulse depression of IACs was not affected or was slightly reduced by $\mathrm{N}_{2} \mathrm{O}(-36 \pm 4 \%$ paired-pulse change in air vs $-27 \pm 7 \%$ change in $\mathrm{N}_{2} \mathrm{O} ; n=14 ; p>0.08$, paired $t$ test; Fig. $10 C$ ), suggesting that a presynaptic potentiation of IACs is unlikely. As another anesthetic comparison, we examined the effect of ketamine on IPSCs. At $100 \mu \mathrm{M}$, a concentration approximately two orders of magnitude higher than anesthetic concentrations (Franks and Lieb, 1994), ketamine had no effect on peak IACs or on total IAC charge transfer $(-4 \pm 8 \%$ change in peak; $6 \pm 9 \%$ change in charge; $n=4$ ).

\section{DISCUSSION}

Our results show that synaptic targets of the widely used inhalation anesthetic $\mathrm{N}_{2} \mathrm{O}$ are confined to postsynaptic sites in hippocampal microcultures. Although a lack of effect of $\mathrm{N}_{2} \mathrm{O}$ on $\mathrm{GABA}_{\mathrm{A}}$ receptors has been reported previously (Little and Thomas, 1986), a recent paper using isolated hippocampal neurons and a local perfusion system similar to that used here found potentiation of responses to exogenously applied muscimol (Dzoljic and Duiijn, 1998). Similarly, a study of invertebrate glutamate receptors reported blockade by $\mathrm{N}_{2} \mathrm{O}$ (Macdonald and Ramsey, 1995). Our present results combined with our previous results (Jevtovic-Todorovic et al., 1998) suggest that several postsynaptic effects may contribute to the anesthetic/analgesic effects of $\mathrm{N}_{2} \mathrm{O}$.

As part of our effort to examine possible presynaptic targets of $\mathrm{N}_{2} \mathrm{O}$, we examined $\mathrm{HVA}$ calcium currents, the general class of calcium current thought to underlie fast neurotransmitter release at glutamate and GABA synapses. We conclude that presynaptic effects via calcium channels are unlikely to underlie the modulation of synaptic transmission observed. Although we cannot eliminate the possibility that the presynaptic terminal may possess a different complement of calcium channels than those examined in the somata, previous studies 


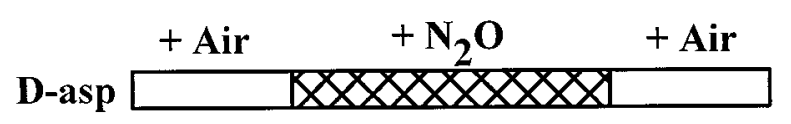

Figure 9. Effect of $\mathrm{N}_{2} \mathrm{O}$ on glial glutamate transporter currents induced by $100 \mu \mathrm{M}$ D-aspartate. The trace shows the response of a microculture glial cell to the application of $100 \mu \mathrm{M}$ D-asp in the presence of air and $\mathrm{N}_{2} \mathrm{O}$. The horizontal bars denote application times.

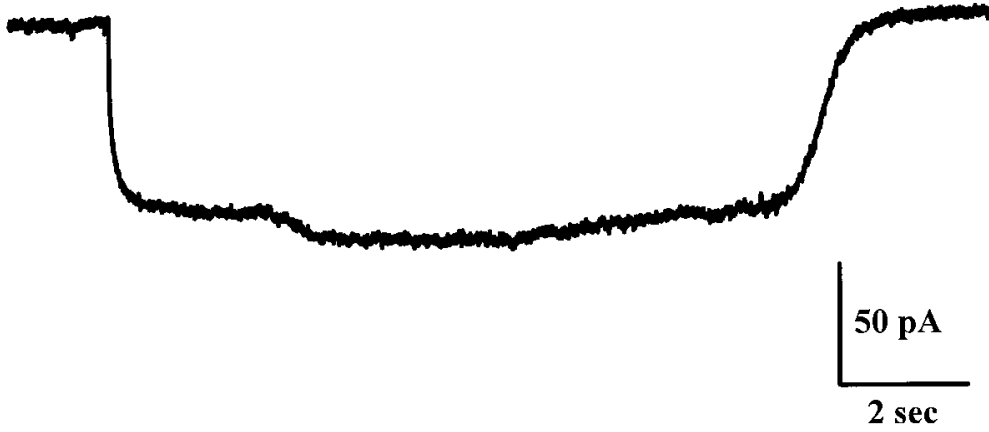

suggest that effects on soma calcium currents are predictive of synaptic effects (Wu and Saggau, 1997).

$\mathrm{N}_{2} \mathrm{O}$ has somewhat nonselective but differential effects on excitatory and inhibitory synaptic currents. It remains to be determined which of the three postsynaptic effects described here might be most important in determining the anesthetic/ analgesic properties of $\mathrm{N}_{2} \mathrm{O}$. Of the three effects of $\mathrm{N}_{2} \mathrm{O}$ detected in the present study, blockade of NMDAR EACs was quantitatively the largest effect of $\mathrm{N}_{2} \mathrm{O}$. Although $\mathrm{GABA}_{A}$ receptors are a common target of many anesthetics, including volatile anesthetics and barbiturates, the effects of $\mathrm{N}_{2} \mathrm{O}$ on IACs were significantly weaker than were the effects of an anesthetically equivalent concentration of pentobarbital (Franks and Lieb, 1994). An anesthetic with the property of an AMPA receptor antagonist has not been described. Because blockade of glutamate receptors and potentiation of $\mathrm{GABA}_{\mathrm{A}}$ receptors would both tend to dampen CNS excitability, it is possible that all three effects work in concert to produce clinical anesthesia. It is of note that the MAC necessary for $\mathrm{N}_{2} \mathrm{O}$ to produce anesthesia in $50 \%$ of rats is $150 \%(\mathrm{v} / \mathrm{v})$ (Gonsowski and Eger, 1994), a concentration unachievable except under hyperbaric conditions. We assume that the effects observed in the present work at subanesthetic concentrations of $\mathrm{N}_{2} \mathrm{O}$ can be extrapolated to anesthetic doses (and may be more pronounced at these doses). However, the extent to which the postsynaptic effects described here underlie the anesthetic/analgesic properties of $\mathrm{N}_{2} \mathrm{O}$ remains to be determined.

Our results do not address the mechanism by which $\mathrm{N}_{2} \mathrm{O}$ blocks ionotropic glutamate receptors and potentiates GABA receptors. Because of the larger magnitude of the effect on NMDA receptors and because of the novelty of this effect, we examined NMDA receptor blockade in most detail. Via these analyses we can make some qualified statements regarding the mechanism of $\mathrm{N}_{2} \mathrm{O}$ block of NMDA receptors. Our previous work showed that $\mathrm{N}_{2} \mathrm{O}$ exhibits a noncompetitive inhibition profile in dose-response relationships (Jevtovic-Todorovic et al., 1998), as does the other clinically used NMDAR antagonist anesthetic ketamine. However, the present work shows that $\mathrm{N}_{2} \mathrm{O}$ blockade of NMDA receptors is much faster and more easily reversible than the block exhibited by ketamine. In addition, the lack of effect on the NMDAR EAC time course suggests that $\mathrm{N}_{2} \mathrm{O}$ is unlikely to possess a use dependence like that of classical local anesthetic agents such as procaine acting at neuromuscular nicotinic acetylcholine receptors (Neher and Steinbach, 1978). The term "uncompetitive inhibition" has been used to describe antagonists with a requirement for agonist binding (Pennefather and Quastel, 1992). Our data show no evidence of an uncompetitive mechanism for $\mathrm{N}_{2} \mathrm{O}$.

A difference in the blockade of AMPA versus NMDA glutamate receptors is the voltage dependence exhibited by $\mathrm{N}_{2} \mathrm{O}$ block of NMDA but not of AMPA receptors. Because $\mathrm{N}_{2} \mathrm{O}$ is not charged, it seems unlikely that this voltage dependence signifies that $\mathrm{N}_{2} \mathrm{O}$ senses the transmembrane electrical field and binds within the channel pore. Our results suggest that the direction of current flow is unlikely to impart apparent voltage dependence to the $\mathrm{N}_{2} \mathrm{O}$ blockade via a knock-on/knock-off type mechanism. Rather, because NMDA receptor gating has been shown to exhibit inherent voltage dependence aside from physiological blockade by $\mathrm{Mg}^{2+}$ (Nowak and Wright, 1992), it is likely that the apparent voltage dependence of $\mathrm{N}_{2} \mathrm{O}$ is caused by increased $\mathrm{N}_{2} \mathrm{O}$ binding to channel conformations adopted preferentially at negative potentials. In contrast, changing the reversal potential of NMDAR currents clearly influences the degree of ketamine and $\mathrm{Mg}^{2+}$ blockade, suggesting that a knock-on/knock-off mechanism likely explains at least part of the apparent voltage dependence of blockade of these two agents (MacDonald and Nowak, 1990).

Ketamine and $\mathrm{Mg}^{2+}$ represent two different classes of molecules that interact with the NMDAR ion channel. Although ketamine exhibits use dependence, $\mathrm{Mg}^{2+}$ apparently is capable of interacting with the closed NMDAR (Nowak et al., 1984; MacDonald et al., 1987; MacDonald and Nowak, 1990). Despite these differences in mechanism, the degree of block by both agents shares strong voltage dependence and at least partial dependence on permeant ion concentration (Fig. 4) $\mathrm{N}_{2} \mathrm{O}$ shares neither of these features. Although our data do not definitively suggest a mechanism of $\mathrm{N}_{2} \mathrm{O}$ action, this dissimilarity between $\mathrm{N}_{2} \mathrm{O}$ and two known channel blockers makes it less likely that $\mathrm{N}_{2} \mathrm{O}$ interacts directly with the NMDAR ion channel.

Although our results suggest that $\mathrm{N}_{2} \mathrm{O}$ targets multiple postsynaptic sites, we failed to detect effects on responses generated by several other classes of transmembrane proteins. We detected no effect on currents mediated by HVA calcium channels, no effect on electrogenic glutamate transporter currents, and no interaction with presynaptic metabotropic glutamate receptors. The lack of $\mathrm{N}_{2} \mathrm{O}$ effect on these responses suggests some specificity of 


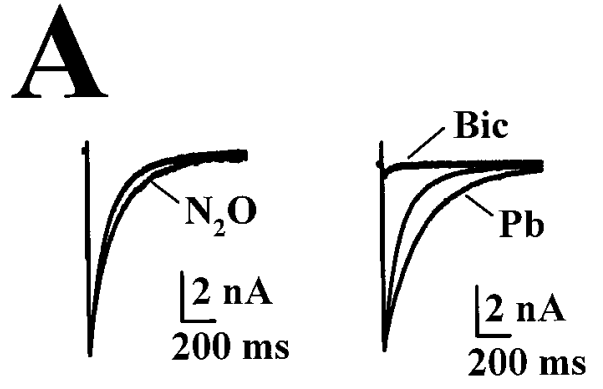

B
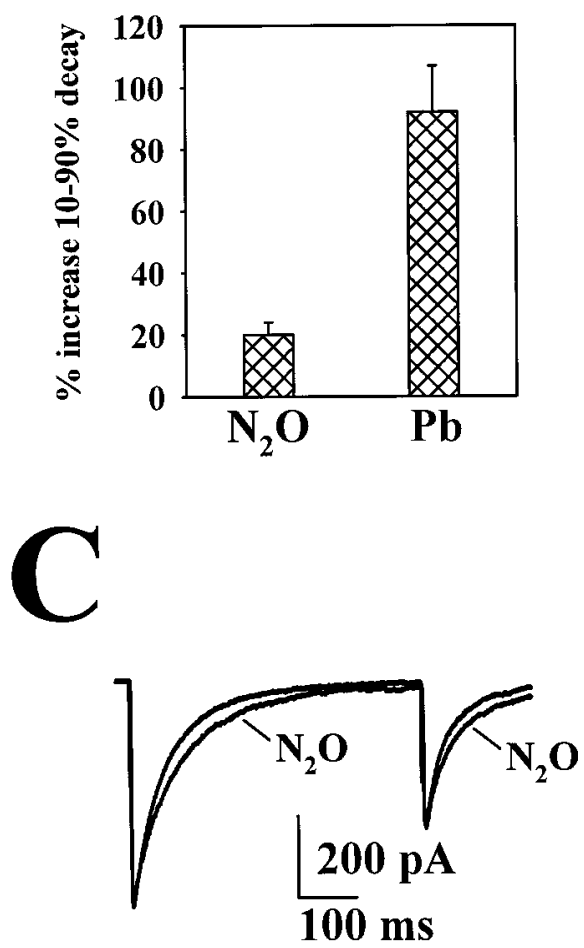

Figure 10. Effect of $\mathrm{N}_{2} \mathrm{O}$ on GABAergic IACs. A, Left, The effect of $\mathrm{N}_{2} \mathrm{O}$ on the IAC in baseline conditions. Right, The effect of $25 \mu \mathrm{M}$ pentobarbital $(\mathrm{Pb})$ on IACs from the same neuron. After the experiment, $25 \mu \mathrm{M}$ bicuculline $(\mathrm{Bic})$ was added to confirm that the response was a GABAergic IAC. Average peak amplitude of 21 baseline IACs was $-4029 \pm 797$ pA. $B$, Summary data showing the effect of $80 \% \mathrm{~N}_{2} \mathrm{O}(n=$ $21)$ and $25 \mu \mathrm{M} \mathrm{Pb}(n=4)$ on the $10-90 \%$ decay time of GABAR IACs. The average 10-90\% decay time for 21 baseline IACs was $101.4 \pm 18.1$ msec. $C$, Paired-pulse stimulation of the GABAergic neuron depicted in $A$ demonstrating that there is no change in paired-pulse depression in cells that show a prolonged IAC. Responses are superimposed IACs in the presence of air and $\mathrm{N}_{2} \mathrm{O}$.

action toward ligand-gated ion channels. The extent to which $\mathrm{N}_{2} \mathrm{O}$ may interact with other classes of ligand-gated ion channels awaits further study.

\section{REFERENCES}

Adams PR (1976) Drug blockade of open end-plate channels. J Physiol (Lond) 260:531-552.

Armstrong CM (1971) Interaction of tetraethylammonium ion deriva- tives with the potassium channels of giant axons. J Gen Physiol 58:413-437.

Armstrong CM, Swenson Jr RP, Taylor SR (1982) Block of squid axon K channels by internally and externally applied barium ions. J Gen Physiol 80:663-682.

Bekkers JM, Stevens CF (1991) Excitatory and inhibitory autaptic currents in isolated hippocampal neurons maintained in cell culture. Proc Natl Acad Sci USA 88:7834-7838.

Bekkers JM, Richerson GB, Stevens CF (1990) Origin of variability in quantal size in cultured hippocampal neurons and hippocampal slices. Proc Natl Acad Sci USA 87:5359-5362.

Brew H, Attwell D (1987) Electrogenic glutamate uptake is a major current carrier in the membrane of axolotl retinal glial cells. Nature 327:707-709.

Clements JD, Lester RA, Tong G, Jahr CE, Westbrook GL (1992) The time course of glutamate in the synaptic cleft. Science 258:1498-1501.

Conn PJ, Pin JP (1997) Pharmacology and functions of metabotropic glutamate receptors. Annu Rev Pharmacol Toxicol 37:205-237.

Dzoljic M, Duiijn BV (1998) Nitrous oxide-induced enhancement of $\gamma$-aminobutyric acid $_{\mathrm{A}}$-mediated chloride currents in acutely dissociated hippocampal neurons. Anesthesiology 88:473-480.

Franks NP, Lieb WR (1994) Molecular and cellular mechanisms of general anaesthesia. Nature 367:607-614.

Gonsowski CT, Eger II EI (1994) Nitrous oxide minimum alveolar anesthetic concentration in rats is greater than previously reported. Anesth Analg 79:710-712.

Herrington J, Stern RC, Evers AS, Lingle CJ (1991) Halothane inhibits two components of calcium current in clonal (GH3) pituitary cells. J Neurosci 11:2226-2240.

Hirofumi M, Nakamura Y, Arai T, Kiyoshi K (1997) Increase of glutamate uptake in astrocytes: a possible mechanism of action of volatile anesthetics. Anesthesiology 86:1359-1366.

Jevtovic-Todorovic V, Todorovic SM, Mennerick S, Powell S, Dikranian K, Benshoff N, Zorumski CF, Olney JW (1998) Nitrous oxide (laughing gas) is an NMDA antagonist, neuroprotectant and neurotoxin. Nat Med 4:460-464.

Kordas M (1970) The effect of procaine on neuromuscular transmission. J Physiol (Lond) 209:689-699.

Legendre P, Rosenmund C, Westbrook GL (1993) Inactivation of NMDA channels in cultured hippocampal neurons by intracellular calcium. J Neurosci 13:674-684.

Little HJ, Thomas DL (1986) The effects of anesthetics and high pressure on the responses of the rat superior cervical ganglion in vitro. J Physiol (Lond) 374:387-399.

Macdonald AG, Ramsey RL (1995) The effects of nitrous oxide on a glutamate-gated ion channel and their reversal by high pressure; a single channel analysis. Biochim Biophys Acta 1236:135-141.

MacDonald JF, Nowak LM (1990) Mechanisms of blockade of excitatory amino acid receptor channels. Trends Pharmacol Sci 11:167-172.

MacDonald JF, Miljkovic Z, Pennefather P (1987) Use-dependent block of excitatory amino acid currents in cultured neurons by ketamine. J Neurophysiol 58:251-266.

MacKinnon R, Miller C (1988) Mechanism of charybdotoxin block of the high-conductance, $\mathrm{Ca}^{2+}$-activated $\mathrm{K}^{+}$channel. J Gen Physiol 91:335-349.

Mayer ML, Westbrook GL (1985) The action of $N$-methyl-D-aspartic acid on mouse spinal neurones in culture. J Physiol (Lond) 361:65-90.

McNaughton BL (1980) Evidence for two physiologically distinct perforant pathways to the fascia dentata. Brain Res 199:1-19.

Mennerick S, Zorumski CF (1994) Glial contributions to excitatory neurotransmission in cultured hippocampal cells. Nature 368:59-62.

Mennerick S, Zorumski CF (1995) Paired-pulse modulation of fast excitatory synaptic currents in microcultures of rat hippocampal neurons. J Physiol (Lond) 488:85-101.

Mennerick S, Que J, Benz A, Zorumski CF (1995) Passive and synaptic properties of neurons grown in microcultures and in mass cultures. J Neurophysiol 73:320-332.

Miao N, Frazer MJ, Lynch III C (1995) Volatile anesthetics depress $\mathrm{Ca}^{2+}$ transients and glutamate release in isolated cerebral synaptosomes. Anesthesiology 83:593-603.

Miller RJ (1990) Receptor-mediated regulation of calcium channels and neurotransmitter release. FASEB J 4:3291-3299.

Neher E, Steinbach JH (1978) Local anesthetics transiently block currents through single acetylcholine-receptor channels. J Physiol (Lond) 277:153-176. 
Nowak L, Bregestoversuski P, Ascher P, Herbert A, Prochiantz Z (1984) Magnesium gates glutamate activated channels in mouse central neurons. Nature 307:462-465.

Nowak LM, Wright JM (1992) Slow voltage-dependent changes in channel open-state probability underlie hysteresis of NMDA responses in $\mathrm{Mg}^{2+}$-free solutions. Neuron 8:181-187.

Pennefather P, Quastel DMJ (1992) Modification of dose-response curves by effector blockade and uncompetitive antagonism. Mol Pharmacol 22:369-380.

Rosenmund C, Clements JD, Westbrook GL (1993) Nonuniform probability of glutamate release at a hippocampal synapse. Science 262:754-757.

Segal MM (1991) Epileptiform activity in microcultures containing one excitatory hippocampal neuron. J Neurophysiol 65:761-770.

Segal MM, Furshpan EJ (1990) Epileptiform activity in microcultures containing small numbers of hippocampal neurons. J Neurophysio 64:1390-1399.

Tong G, Jahr CE (1994a) Multivesicular release from excitatory synapses of cultured hippocampal neurons. Neuron 12:51-59.

Tong G, Jahr CE (1994b) Block of glutamate transporters potentiates postsynaptic excitation. Neuron 13:1195-1203.

Wadiche JI, Amara SG, Kavanaugh MP (1995) Ion fluxes associated with excitatory amino acid transport. Neuron 15:721-728.

Wilding TJ, Huettner JE (1997) Activation and desensitization of hippocampal kainate receptors. J Neurosci 17:2713-2721.

Wu LG, Saggau P (1997) Presynaptic inhibition of elicited neurotransmitter release. Trends Neurosci 20:204-212.

Zorumski CF, Yang J, Fischbach GD (1989) Calcium-dependent, slow desensitization distinguishes different types of glutamate receptors. Cell Mol Neurobiol 9:95-104. 